\title{
Development of Durable Exterior Insulation Finishing Systems Based on Composite Timber Technology for Building Facades
}

\author{
A.V. Erofeev*, V.P. Yartsev \\ Department of Construction of Buildings and Structures, Tambov State Technical University, \\ 112, Michurinskaya St., Tambov, 392032, Russian Federation \\ * Corresponding author. Tel.: + 7 (910) 85167 44.E-mail: av-erofeev@ya.ru
}

\begin{abstract}
Today, the requirements to thermal insulation of buildings and structures are increasing. Insulation has become an essential part of regulatory thermal protection of buildings. The analysis of the advantages and drawbacks of the existing insulation systems has shown that the most suitable system is the one with the insulation layer located outside the building. Such system of insulation is based on the use of an additional layer, called finishing or cladding, placed on top of the insulation layer to ensure the protection of buildings against atmospheric agents. The purpose of this study was to develop a material for exterior finish cladding of buildings. We developed a composite timber cladding system in the form of laminated composite material consisting of a substrate (base), a binder and a decorative layer. Manufacturing process comprised four stages. Atmospheric effects were modeled according to the GOST climatic test methods. For the rational use of material resources we calculated the optimal material consumption per unit area for the decorative layer. Durability of cladding depends on the substrate material. Under the effect of atmospheric agent the durability of cladding decreases. Heat and ultraviolet exposure causes decrease in durability of cladding after the completion of resin polymerization, which initially leads to an increase in durability. The impact of aggressive media solutions also results in reduced durability of cladding. Durability of cladding depends on the strength characteristics of the substrate. An operation life of cladding is determined by the difference between the mass of cladding with optimal material consumption per unit area for the decorative layer and the mass of similar cladding with the least possible material consumption per unit area for the decorative layer from an aesthetic perspective. The operational life of the developed cladding is at least 15 years. The cement chipboard-resin compound has low adhesive strength, which leads to the conclusion about the impossibility of using cement chipboard as the substrate for decorative cladding. High humidity deformation limits the use of wood particleboards and MDF as a substrate for cladding. Thus, we recommend using WBP plywood as a substrate for the cladding. The economic rationale is based on the comparison of the following materials used for exterior finishing systems: plywood, facing bricks, porcelain stoneware and vinyl siding.
\end{abstract}

\section{Keywords}

Atmospheric agents; durability; exterior design; heat insulation solutions; insulation protection; timber composites.

(C) A.V. Erofeev, V.P. Yartsev, 2016

\section{Introduction}

For many years the construction industry in Russia has been focusing on mass production of single-walled precast concrete structures with little regard to energy-saving. This economically unreasonable approach can be explained by the low cost of fuel and energy resources in our country [1]. However, with the alarming growth of energy consumption in the world in the past few decades, the problem of energy conservation in construction has become more relevant [2]. One of the key areas of energy conservation policy in the construction industry is to improve the thermal protection of buildings, which will reduce their energy consumption by $20-30 \%$. This results in the stricter requirements for thermal protection of buildings and structures.

The main potential for energy conservation is related to the operational characteristics of structures; in this connection the reduction in the energy consumption can be achieved by improving thermal insulation qualities of walling to the level of regulatory requirements [3]. To ensure regulatory thermal insulation of reconstructed or newly erected buildings 
it is necessary to use proper insulation. Most buildings have low operational characteristics; therefore it is necessary to protect them from adverse external weather conditions. There are two options of insulation arrangement to protect the building from weather conditions $[4,5]$. In the first case the insulation is located in the body of the structure, so that its bearing part is exposed to an atmospheric action. In the second case, the insulation is located outside the building with an additional layer arranged on the top of it; this layer is called finishing, which simultaneously performs two functions: it protects the insulation from the weather conditions, and gives the facade of the building a unique appearance. The choice of the insulation system is made on the basis of the analysis of its advantages and disadvantages.

Trouble-free service life of insulation in a multiwall structure is significantly lower than that of a bearing structure material. Trouble-free service life is understood as the ability of material to maintain its properties under certain conditions of operation without forced breaks for repair. Thus, the insulation layer in a multi-wall structure must be periodically visually monitored and repaired where necessary, which is problematic for the "sandwich" type of insulation systems, in which the insulation layer is located between the supporting structures (Fig. $1 a$ ).

If the insulation layer is placed inside the building (Fig. $1 b$ ) where intermediate floors are supported by load-bearing walls, or at the junction of internal loadbearing walls or partitions to the external walls, the socalled thermal bridges increase heat transfer, thus causing a number of negative effects, such as:

- increased power consumption for heating of a building;

- buildup of condensate, accumulation of moisture and mold growth on the surface of building elements due to lower temperature.

The negative impact of thermal bridges can be eliminated by increasing the thickness of the insulation. However, this will lead to deterioration of the aesthetic qualities and overexpenditure of building materials. The disadvantages of such insulation system are the need for dismantling radiators and disassembly of floors in the places of their adjunction to exterior walls during insulation works. This also involves

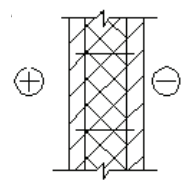

a)

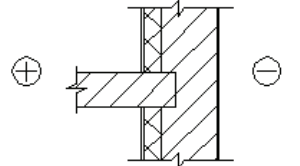

b)

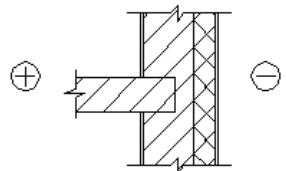

c)
Fig. 1. Thermal insulation for buildings:

$a$-insulation between the supporting structures; $b-$ insulation inside the building; $c$-insulation outside the building relocating residents, thus causing additional inconvenience.

Arrangement of additional insulation outside the building (Fig. $1 c$ ) avoids the disadvantages of the previous option: floor area remains the same, there is no need for relocating residents, or creating uncomfortable living conditions, the problem of thermal bridges occurrence is eliminated. The considered embodiment provides protection of insulation material of supporting structures from negative atmospheric impact, which leads to an increase in its longevity. Also, the possibility of cracking caused by nonuniform thermal deformation is eliminated, which results in increased durability of the main load-bearing structures. When placing the insulation outside the building, the temperature in the main body of the walls is less fluctuating. The advantages of the considered embodiment include the dew point shifting to the external insulation layer, reducing the possibility of moisture accumulation inside the wall, and creating a favorable environment inside the wall, thus eliminating the need for steam insulation.

The disadvantages of external thermal insulation for buildings include the need for a special means of paving and the need for protection of the thermal insulation layer which has quite low performance characteristics. Developing durable exterior finishing systems for building facades is a perfect solution to the problem of insulation layer protection against atmospheric agents.

The analysis of the advantages and disadvantages of different insulation systems showed that the system in which the insulation layer is located outside the building is optimal [6]. When choosing a particular type of cladding the cost and environmental friendliness of materials play a very important role. Despite the diversity of exterior design materials, none of them has an optimum combination of parameters: performance properties, aesthetic appearance, cost, and environmental friendliness. Therefore, the aim is to develop durable insulation finishing systems based on composite timber technology for exterior design of buildings with an optimal combination of the above properties.

\section{Experimental}

We developed exterior insulation finishing system for building facades in the form of laminated wood composite, consisting of a substrate (base), a binder material and a decorative layer (Fig. 2).

We propose to use the following materials as the base for the cladding system: CBPB-1 cement chipboard, P-B chipboard, fiberboard, WBP plywood [7]. These materials are widespread, have good thermal insulation properties and the ability to create a 
durable adhesive bond with the resin. The following thermosetting resins: PN-1 polyester resin and ED-20 epoxy resin can be used as a binder as they become environmentally safe after polymerization [7]. The decorative layer can be made from the following materials: expanded clay sand fraction of $0-5 \mathrm{~mm}$ with a particle size of 0.14 to $5 \mathrm{~mm}$, softwood sawdust at least $5 \mathrm{~mm}$ and a humidity of $10 \%$, and natural sand of average particle size [7]. The choice of material for the decorative layer is determined by low cost and availability.

Manufacturing technology of exterior insulation finishing systems consists of four main stages [8]. In the first stage of production the panels of the required size are cut from the selected bases for further cleaning from dust, oil stains, etc.

Due to the fact that the complete polymerization of the resin requires two additional components (accelerator and catalyst) in the second stage the following operations are performed: 1) calculating the required amount of resin; 2) adding an accelerator to the resin $(0.5 \%$ by weight of polyester resin); 3 ) mixing the resin with the accelerator for two minutes; 4) adding a catalyst to the obtained resin ( 2 and $10 \%$ by weight of the polyester and epoxy resins, respectively); 5) stirring the resulting resin with the catalyst for two minutes. For polyester resin cobalt naphthenate is used as the accelerator, and methyl ethyl ketone peroxide is used as the catalyst. The catalyst (polyethylene polyamine) is added only to the epoxy resin.

In the third stage the prepared binder is applied to the substrate during the pot life of the adhesive composition (30 to $60 \mathrm{~min}$ ). By the pot life of the resin we mean the time elapsed from the introduction of the catalyst to a gelatinous state. The binder should be applied uniformly with a thickness of 1-2 mm using special equipment for applying adhesives.

In the last stage of production the material for the decorative layer is applied to the binder. Technological break between the third and fourth stages should not exceed $5 \mathrm{~min}$. It takes 2 days to finish the process of resin polymerization. The process takes place at a room temperature. With an increase in the temperature the rate of polymerization increases.

Atmospheric effects were simulated through climatic tests: 1) systematic temperature variation in autumn and spring was simulated by freeze-thaw cycles in the following order: soaking for $2 \mathrm{hrs}$, freezing at $-30{ }^{\circ} \mathrm{C}$ for $2 \mathrm{hrs}$, thawing at temperatures ranging from 20 to $40{ }^{\circ} \mathrm{C}$ for $4 \mathrm{hrs}$. (GOST 28199-89); 2) the effect of high temperatures in summer was simulated by heat aging in a heat chamber at a temperature of $+80^{\circ} \mathrm{C}$ (GOST 28200-89); 3) the effect

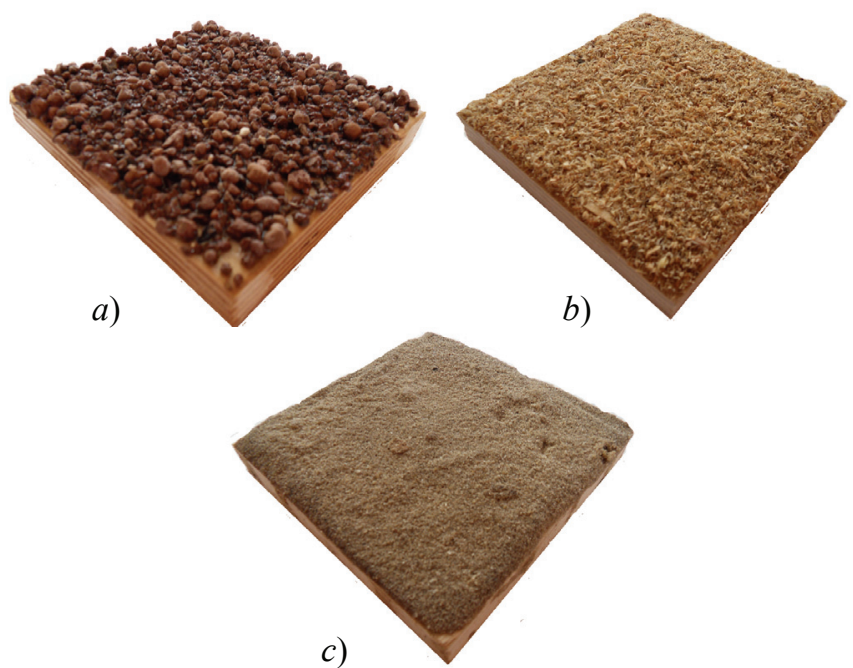

Fig. 2. Exterior insulation finishing systems with decorative layer made from (a) expanded clay sand, $(b)$ softwood sawdust, (c) natural sand

of sunlight exposure was simulated by ultraviolet radiation using DRT-1000 lamp (GOST 28202-89).

Testing of properties of exterior insulation finishing systems was conducted according to the GOST methods on samples of sizes $1 \times 5,1 \times 12,5 \times 5$ and $10 \times 10 \mathrm{sm}$.

\section{Results and Discussion}

For the rational use of material resources for the production of exterior insulation finishing systems one must know the optimum consumption rate of the decorative layer material per unit area, which was determined experimentally by applying to the base material of the decorative layer weight of 20,40, 60 and $80 \%$ of the maximum. The optimal consumption rate of expanded clay sand was $80 \%\left(2.94 \mathrm{~kg} / \mathrm{m}^{2} /\right.$ $2.1 \mathrm{~kg} / \mathrm{m}^{2}$ ) of the maximum, of the sawdust it was $60 \%\left(0.251 \mathrm{~kg} / \mathrm{m}^{2} / 0.083 \mathrm{~kg} / \mathrm{m}^{2}\right)$ and of the natural sand it was $40 \%\left(0.276 \mathrm{~kg} / \mathrm{m}^{2} / 0.152 \mathrm{~kg} / \mathrm{m}^{2}\right)$ for systems with a polyester / epoxy binder [9].

The basic operational strength characteristics of exterior insulation finishing systems are transverse bending strength, adhesion strength of "binder-base" and hardness of the decorative layer.

A relatively small variation in transverse bending strength (Table 1) for exterior insulation finishing systems with a similar base brings us to the conclusion that the strength of the system mainly depends on the base material [10]. This conclusion makes it possible to reduce the cost of exterior insulation finishing systems by applying cheap kinds of resins. However, such a substitution should not degrade the environmental friendliness of the product. 
Table 1 around the equilibrium position. There is a possibility

The transverse bending strength for exterior insulation finishing systems

\begin{tabular}{|c|c|c|c|c|}
\hline \multirow{2}{*}{$\begin{array}{l}\text { Base } \\
\text { type }\end{array}$} & \multirow{2}{*}{$\begin{array}{l}\text { Binder } \\
\text { type }\end{array}$} & \multicolumn{3}{|c|}{$\begin{array}{l}\text { Transverse bending strength, } \\
\mathrm{MPa} \text {, for systems with } \\
\text { decorative layer made from: }\end{array}$} \\
\hline & & $\begin{array}{l}\text { expanded } \\
\text { clay sand }\end{array}$ & sawdust & $\begin{array}{c}\text { natural } \\
\text { sand }\end{array}$ \\
\hline \multirow{2}{*}{$\begin{array}{l}\text { Cement } \\
\text { chipboard }\end{array}$} & Polyester resin & 5.622 & 9.861 & 9.598 \\
\hline & Epoxy resin & 5.829 & 9.602 & 11.41 \\
\hline \multirow{2}{*}{$\begin{array}{l}\text { Wood } \\
\text { chip } \\
\text { board }\end{array}$} & Polyester resin & 11.598 & 8.759 & 12.29 \\
\hline & Epoxy resin & 12.2 & 8.61 & 10.155 \\
\hline \multirow{2}{*}{$\begin{array}{l}\text { Wood } \\
\text { fiber } \\
\text { board }\end{array}$} & Polyester resin & 28.434 & 24.281 & 26.368 \\
\hline & Epoxy resin & 22.826 & 27.978 & 25.481 \\
\hline \multirow{2}{*}{ Plywood } & Polyester resin & 51.813 & 51.469 & 52.695 \\
\hline & epoxy resin & 55.151 & 51.987 & 54.82 \\
\hline
\end{tabular}

Change in the strength of exterior insulation finishing systems is subject to dependence after heat and ultraviolet aging [11]

$$
\sigma=a_{\sigma} t^{2}+b_{\sigma} t+c_{\sigma},
$$

and cyclic freeze-thaw [11]

$$
\sigma=a_{\sigma} n^{2}+b_{\sigma} n+c_{\sigma},
$$

where $\sigma$ is transverse bending strength, MPa; $t$ is the duration of the considered weather conditions, hrs; $n$ is the number of freeze-thaw cycles, units; $a_{\sigma}, b_{\sigma}, c_{\sigma}$ are coefficients depending on the type of substrate, the binder and the decorative layer material, and the type of impact. The coefficient $c_{\sigma}$ determines the strength of the original decorative and protective panels.

The strength of the decorative layer decreases under cyclic freeze-thaw, which is explained by the destruction of the liquid material in the transition from one state to another with the increase in the volume. Under heat and ultraviolet aging there is an increase in initial strength caused by further polymerization of thermosetting resin. After completion of the resin polymerization the strength of the decorative and protective panels began to fall. Decrease in the strength of exterior insulation finishing systems exposed to heat aging is explained from the perspective of thermofluctuation concept. A kinetic unit, located in a potential well, fluctuates that at some point in time it will be able to overcome the energy barrier. Consequently, the kinetic units lose their position forming a defect in the structure of a material. As the temperature increases, the likelihood of defects increases. The formation of a large number of defects leads to a decrease in strength.

Decrease in the strength of exterior insulation finishing systems and the hardness of the decorative layer after UV aging is caused by the fact that the level of UV radiation is higher than the level at which there is destruction of chemical bonds in the polymer chains. Therefore, the absorbed energy causes the destruction of the weakest chemical bonds. It is accompanied by the formation of active free radicals, which initiate the degradation of the polymer.

The impact of active liquid environments on the properties of exterior insulation plywood-based finishing systems was considered using fresh and salt water, $10 \%$ solutions of sulfuric and hydrochloric acids, which are part of acid rain. This choice of liquids is explained by the fact that there is a possibility of system operation in such conditions. The experiments showed that durability of exterior insulation plywood-based finishing systems decreased in accordance with the logarithmic dependence. The experimental relations (Table 2) allowed calculating the strength of exterior insulation plywoodbased finishing systems using the data on their operation in aggressive environments.

The least reduced strength of exterior insulation finishing systems is observed on the seventh day after exposure to fresh and salt water. For this material water is not a chemically aggressive environment. It only facilitates mechanical degradation by increasing the distance between the acromolecules.

Exposure to $10 \%$ solutions of the considered acids leads to chemical degradation of the system. Exposure to $10 \%$ solutions of sulfuric and hydrochloric

Table 2

The experimental relations between strength decrease of exterior insulation plywood-based finishing systems with sawdust decorative layer and the time of aggressive environment exposure

\begin{tabular}{lcc}
\hline $\begin{array}{c}\text { Type and concentration } \\
\text { of aggressive environment }\end{array}$ & Polyester resin & Epoxy resin \\
\hline Fresh water & $-2.9845 \ln (t)+38.216$ & $-2.9086 \ln (t)+36.58$ \\
Salty water $(10 \%)$ & $-2.538 \ln (t)+40.45$ & $-2.5635 \ln (t)+42.21$ \\
Hydrochloric acid $(10 \%)$ & $-6.2249 \ln (t)+29.035$ & $-6.3884 \ln (t)+29.767$ \\
Sulfuric acid $(10 \%)$ & $-5.9686 \ln (t)+32.502$ & $-6.2123 \ln (t)+30.576$ \\
\hline
\end{tabular}




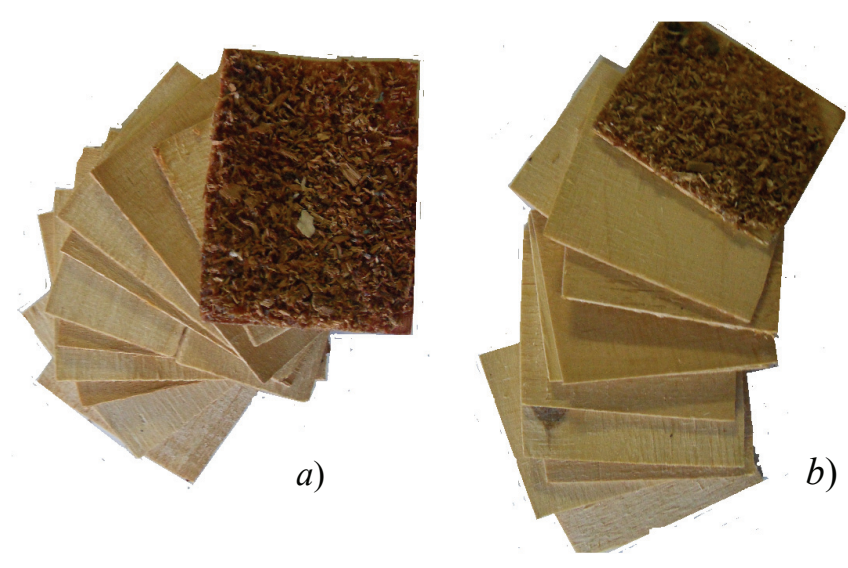

Fig. 3. Exterior insulation plywood-based finishing system with a binder of polyester resin and sawdust as the material of the decorative layer after exposure to $10 \%$ solution of $(a)$ sulfuric acid, (b) hydrochloric acid

acids within a day leads to the complete destruction of the base, i.e. separation of plywood veneer (Fig. 3). Therefore, we can conclude that these solutions of acids destroy the chemical bond in the main chain of the macromolecule. With increasing acid concentration, the rate of the chemical degradation increased.

After exposure to $10 \%$ solutions of sulfuric and hydrochloric acids exterior insulation finishing systems changed their color. Thus the decorative layer and the base of the system after exposure to the sulfuric acid became brown, and after exposure to hydrochloric acid they became dark yellow.

Considering that the strength of the exterior insulation finishing systems is determined by the strength of the substrate, it is logical to assume that the life of the considered exterior insulation finishing systems will also be determined by the durability of the substrate. If the hypothesis is confirmed, then the durability of the substrate can be considered as the durability of the exterior insulation finishing systems as a whole. Therefore, we will calculate the constants in the Zhurkov's generalized equation (3) only for two exterior insulation finishing systems: plywood-based systems, with a binder of polyester and epoxy resin and sawdust as the material of the decorative layer.

The Zhurkov's generalized equation has the form:

$$
\tau=\tau_{\mathrm{m}} \exp \left[\frac{U_{0}-\gamma \sigma}{R}\left(T^{-1}-T_{\mathrm{m}}^{-1}\right)\right],
$$

where $\tau_{\mathrm{m}}, U_{0}, \gamma$ и $T_{\mathrm{m}}$ are physical constants of the material; $\tau_{\mathrm{m}}$ is oscillation period of kinetic units, $\mathrm{s}$; $U_{0}$ is maximum activation energy of destruction, $\mathrm{kJ} / \mathrm{mol} ; \gamma$ is structural and mechanical constant $\mathrm{kJ} /(\mathrm{mol} \cdot \mathrm{MPa}) ; T_{\mathrm{m}}$ is ultimate temperature of solid body, $\mathrm{K} ; R$ is universal gas constant, $\mathrm{kJ} /(\mathrm{mol} \cdot \mathrm{K}) ; \tau$ is durability, $\mathrm{s} ; \sigma$ is stress, $\mathrm{MPa} ; T$ is temperature, $\mathrm{K}$.

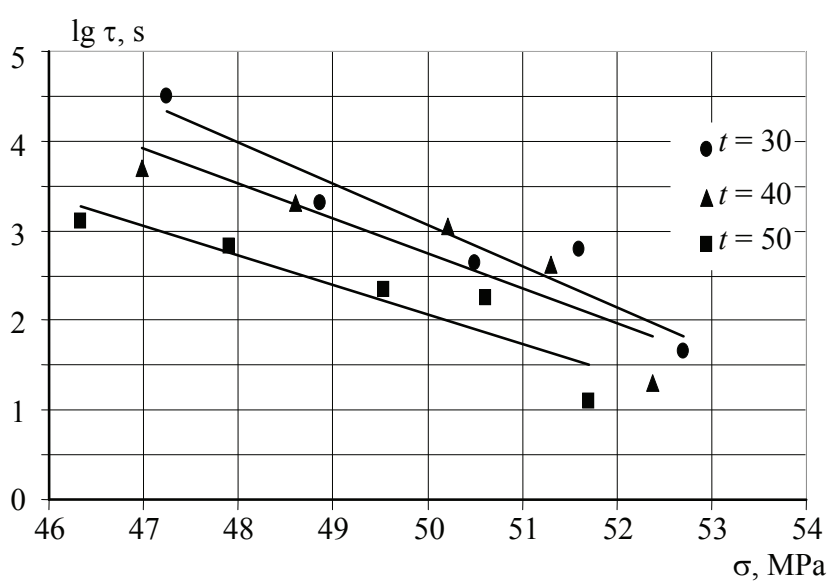

Fig. 4. Dependence of the time before the destruction of exterior insulation plywood-based finishing system with a binder of an epoxy resin and sawdust on stresses in transverse bending

Table 3

Constants in the Zhurkov's generalized equation

\begin{tabular}{|c|c|c|c|c|}
\hline Material & $\tau_{0}, \mathrm{~s}$ & $T_{\mathrm{m}}, \mathrm{K}$ & $\begin{array}{c}U_{0}, \\
\mathrm{~kJ} / \mathrm{mol}\end{array}$ & $\begin{array}{c}\gamma, \\
\mathrm{kJ} /(\mathrm{mol} \cdot \mathrm{MPa})\end{array}$ \\
\hline $\begin{array}{l}\text { WBP } \\
\text { plywood }\end{array}$ & $10^{-0,88}$ & 369 & 633 & 7 \\
\hline \multicolumn{5}{|c|}{$\begin{array}{c}\text { Exterior insulation plywood-based finishing system } \\
\text { with a binder of: }\end{array}$} \\
\hline $\begin{array}{l}\text { Polyester } \\
\text { resin }\end{array}$ & $10^{-1}$ & 454.5 & 701 & 15.85 \\
\hline Epoxy resin & $1.86 \cdot 10^{-1}$ & 400 & 963 & 18.4 \\
\hline
\end{tabular}

For the considered exterior insulation finishing systems in the temperature range from 20 to $60{ }^{\circ} \mathrm{C}$ we obtained a family of fan-shaped lines (Fig. 4), converging at the point (pole). The constants obtained from the Zhurkov's generalized equation allowing for estimation of the strength durability of the system are summarized in Table 3.

Calculation of the constants in the Zhurkov's generalized equation by graphoanalytical method provides a number of unavoidable uncertainties, and given similar values (Table 3 ) of the obtained constants it can be argued that the proposed hypothesis is true.

The change in mass of the samples exposed to atmospheric agents, taking into account human impact is subject to the relationship:

$$
M=a_{1} n^{2}+b_{1} n,
$$

where $M$ is change in the mass of the system exposed to the cycles of atmospheric effects, $\% ; n$ is the number of cycles of atmospheric effects, pcs.; $a_{1}, b_{1}$ are coefficients depending on the type of substrate of 
the binder and the material of the decorative layer as well as the type exposure.

After the freeze-thaw cycles, taking into account the human impact we observed an increase in the mass of the samples caused by the residual moisture after drying. The heat and ultraviolet aging combined with the human impact led to a decrease in the mass of the samples caused by crumbling of the material of the decorative layer under the influence of a foreign body.

An operation life of cladding is understood as the period of time when the exterior insulation finishing system preserves the decorative function under the influence of atmospheric agents. Operational life is a conditional value as a decorative function is estimated visually and depends on an expert's opinion. The method of calculating the operational life is reduced to calculating the difference between the mass of the exterior insulation design system with optimal material consumption per unit area for the decorative layer and the mass of similar cladding with the least possible material consumption per unit area for the decorative layer. Then, using the obtained dependencies we calculated the time required for the mass difference to exceed the calculated difference.

The compounds "Polyester resin-Cement chipboard" (0.53 MPa) and "Epoxy resin - Cement chipboard" $(0.74 \mathrm{MPa})$ proved to have the lowest adhesion strengths. This fact is explained from the perspective of the mechanical theory of adhesion: cement chipboard has low surface roughness ( 80 microns) and porosity, so the resin does not impregnate the boundary layers. Consequently, the contact area in this case is much lower than the contact area in the compounds "Polyester resin-Wood chipboard" and "Epoxy resin - Plywood", in which the boundary layers of the resin impregnate the substrate.

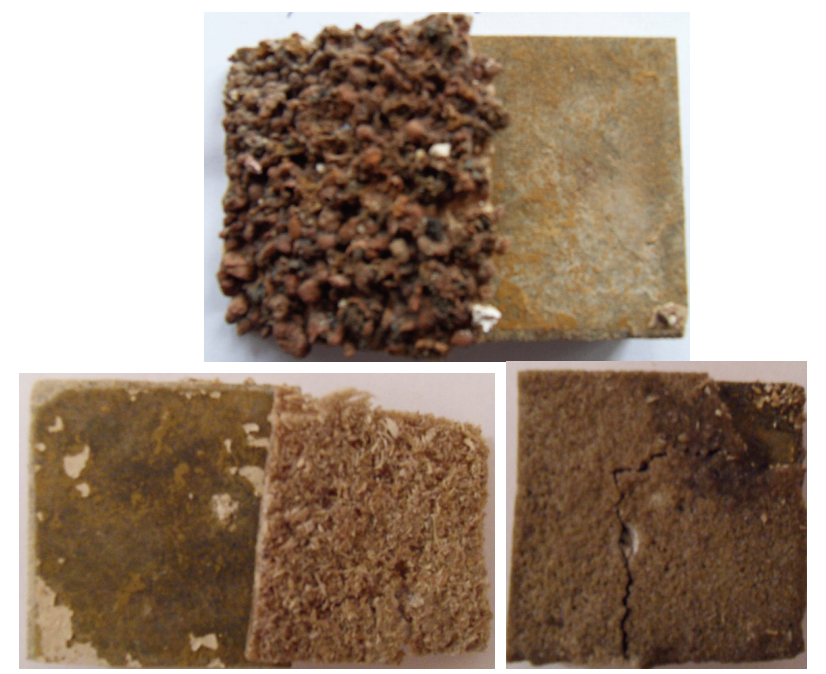

Fig. 5. Separation of the decorative layer from the cement chipboard-based substrate after freeze-thaw cycles
Moreover, in the first case, the impregnation depth is several times higher than that in the second case. According to the mechanical theory, the adhesive strength of "Polyester resin-Wood chipboard" $(1.4 \mathrm{MPa})$ and "Epoxy resin-Wood chipboard" (1.55 MPa) should be higher than that for the compounds "Polyester resin - Plywood" (2.4 MPa) and "Epoxy resin - Plywood" (3.17 MPa). Empirically obtained data gave a diametrically opposite picture. This is explained by the fact that the destruction of bonds occurs outside the impregnation zone of boundary layers, i.e. it causes adhesive rather than cohesive failure.

Decorative protective panels based on wood chip board with a binder of polyester and epoxy resins did not survive four and eight of freeze-thaw cycles, respectively, as delamination of the decorative layer from the substrate occurred (Fig. 5). This fact also confirms the conclusion about the low adhesion strength of "Wood chip board - Polyester resin" and "Wood chip board - Epoxy resin" [7].

The experiment showed that the hardness of the decorative layer of exterior insulation finishing systems depends on many factors: the material of the decorative layer, its fractional composition and distribution pattern, binder, and base. Thus, even the use of identical starting materials does not give constant values of the hardness of the decorative layer, i.e. the obtained hardness values of the decorative layer should be considered as conditional values [12]. Changes in the hardness of the decorative layer exposed to atmospheric agents in most cases are subject to the dependence similar to dependence (2).

Another important characteristic in the production of exterior insulation finishing systems is water absorption. The processes of water absorption and swelling are caused by filling of macro-capillaries and pores of the material. It was established experimentally that the process of water absorption for exterior insulation finishing systems is described by a logarithmic dependence [13]

$$
W=a_{w} \ln (t)+b_{w}
$$

where $a_{w}$ is the slope of water absorption built in logarithmic coordinates.

Thus, the process of water absorption is most intensive in the initial period, with its further stabilization. The speed of the process of water absorption is a derivative of the function of water absorption and has the form

$$
v_{w}=a_{w} / t
$$

Consequently, the coefficient $a_{w}$ defines the velocity of water absorption. 


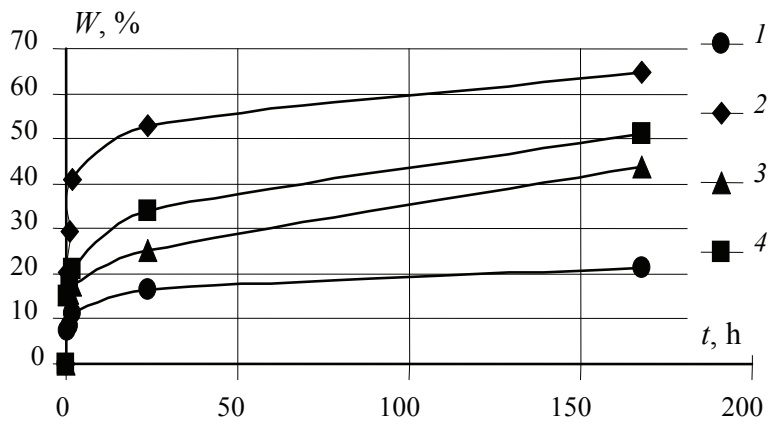

a)

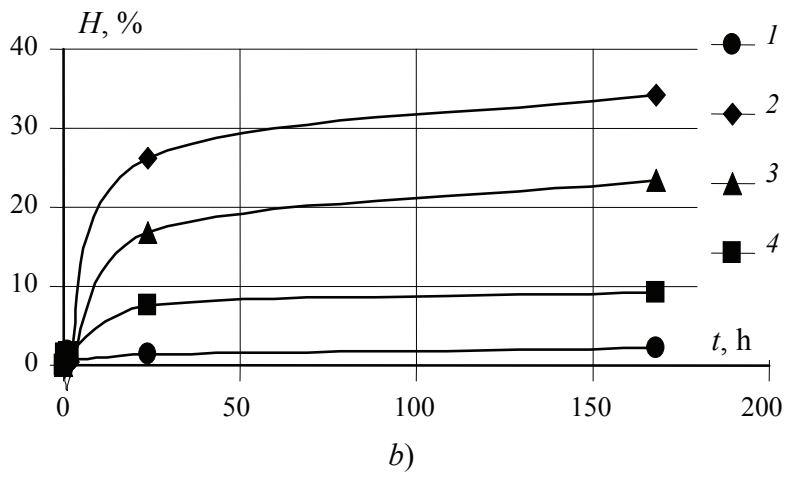

b)

Fig. 6. The relation between water absorption $(a)$ and swelling $(b)$, and the duration of soaking for exterior insulation finishing systems based on:

1 - cement chipboard; 2 - wood chipboard; 3 - fiberboard; 4 - plywood, and decorative layer made from sawdust

For exterior insulation finishing systems the swelling process is described by the dependence similar to the dependence (5). Although the processes of water absorption and swelling are subject to the logarithmic dependence, their velocity depends on the water absorption and swelling of the substrate (Fig. 6).

It was found that the level of water absorption and swelling processes when using an identical binder material and the decorative layer for exterior insulation finishing systems based on wood chipboard was maximum, but for those based on cement chipboard it was minimum. The type of binder does not directly influence the process of water absorption and swelling. This is due to the fact that resins have similar properties, and their weight is negligible in comparison with the mass of the substrate. However, it should be noted that resins are used to adhere different amounts of the material of the decorative layer, thus having an indirect influence on the process of water absorption and swelling of the systems.

The main operating thermal physical properties of exterior insulation finishing systems are thermal resistance, coefficient of thermal expansion and thermal conductivity.

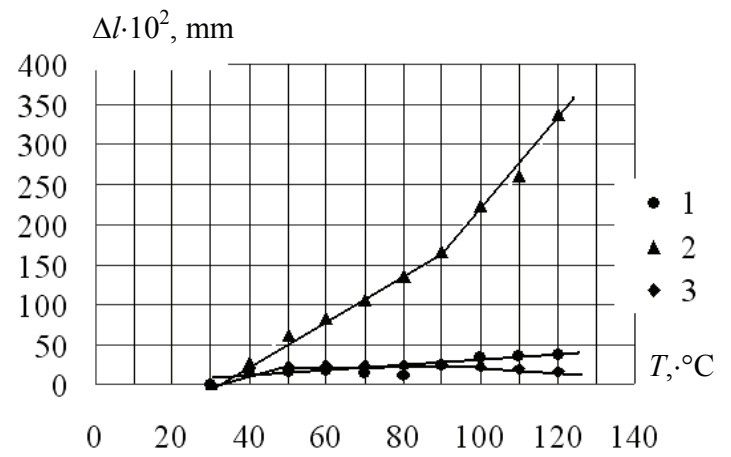

a)

Fig. 7. Dilatometric curve:

1 - plywood; 2 - polyester resin $(a)$, epoxy resin $(b) ; 3$ - exterior insulation plywood-based finishing system

with a binder of polyester resin $(a)$ epoxy resin $(b)$ and sawdust decorative layer

The coefficient of linear thermal expansion of the product based on plywood with a binder of polyester resin was $5.82 \cdot 10^{-7}{ }^{\circ} \mathrm{C}^{-1}$, and with a binder of epoxy resin it was $2.92 \cdot 10^{-6}{ }^{\circ} \mathrm{C}^{-1}$.

The arrangement of dilatometric curves in Fig. 7 shows that plywood hinders the process of expanding the polyester resin (dilatometric curve of the panel is located near the dilatometric curve of the plywood) [15].

The arrangement of dilatometric curves in Fig. $7 b$ shows that the epoxy resin only partially impregnates the upper layer of plywood, and the rest of the resin can expand freely (dilatometric curve of a decorative protective panel is located near the dilatometric curve of epoxy resin) [15].

The tests showed that for the considered exterior insulation finishing systems the difference of thermal expansion coefficients of the starting materials did not destroy the composite material.

The type of atmospheric exposure and its duration did not affect the nature of the dilatometric curves. However, the coefficient of linear thermal expansion changed after the atmospheric exposure, indicating that small changes occurred in the structure of the material.

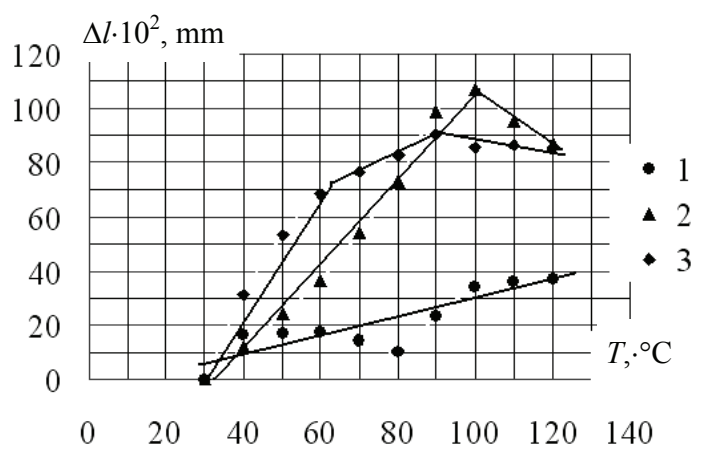

b) 
Table 4 design solution [7]. It is not expedient to use products

Reasons for failure of bases for exterior insulation finishing systems

\begin{tabular}{|c|c|c|}
\hline \multirow{2}{*}{$\begin{array}{l}\text { Type } \\
\text { of base }\end{array}$} & \multicolumn{2}{|c|}{ Type of binder } \\
\hline & Polyester resin & Epoxy resin \\
\hline $\begin{array}{l}\text { Cement } \\
\text { chipboards }\end{array}$ & $\begin{array}{l}\text { Low adhesion strength } \\
\text { of "Cement chipboard - } \\
\text { Polyester resin" } \\
\text { composite (failed } 4 \\
\text { freeze-thaw cycles) }\end{array}$ & $\begin{array}{l}\text { Low adhesion strength } \\
\text { of "Cement chipboard - } \\
\text { Polyester resin" } \\
\text { composite (failed } 8 \\
\text { freeze-thaw cycles) }\end{array}$ \\
\hline $\begin{array}{l}\text { Wood } \\
\text { chipboard }\end{array}$ & $\begin{array}{l}\text { High humidity } \\
\text { deformation (swelling } \\
\text { up to } 30 \% \text { for } 24 \mathrm{hrs)}\end{array}$ & $\begin{array}{l}\text { High humidity } \\
\text { deformation (swelling } \\
\text { up to } 30 \% \text { for } 24 \mathrm{hrs)}\end{array}$ \\
\hline $\begin{array}{l}\text { Fiber } \\
\text { board }\end{array}$ & $\begin{array}{l}\text { Warping of panels } \\
\text { under cyclic }\end{array}$ & $\begin{array}{l}\text { Warping of panels } \\
\text { under cyclic }\end{array}$ \\
\hline & soaking-drying & soaking-drying \\
\hline
\end{tabular}

The coefficients of thermal conductivity of exterior insulation plywood-based finishing systems depending on the type of the binder material and the decorative layer were in the range of 0.116 to $0.123 \mathrm{~W} /(\mathrm{m} \cdot \mathrm{K})$. The thermal conductivity of plywood $(0.12 \mathrm{~W} /(\mathrm{m} \cdot \mathrm{K}))$ declined within the resulting range. Consequently, the types of the binding material and the decorative layer have practically no influence on the thermal conductivity and thermal resistance of exterior insulation finishing systems, which are determined by the thermal physical properties of the system base.

The economic rationale was based on the comparison of the following materials used for exterior finishing systems: plywood, facing bricks, porcelain stoneware and vinyl siding. We made estimates for a three-story two-entrance brick residential building with a total area of $700 \mathrm{~m}^{2}$ and brick wall thickness of $510 \mathrm{~mm}$. The area of the proposed construction is the city of Tambov. The cost of facade cladding varied depending on the type of selected material and accounted for 1,222,200 Russian rubles for plywood, $1,712,200$ Russian rubles for facing bricks, $1,867,600$ Russian rubles for porcelain stoneware and 747,600 for vinyl siding finishing.

\section{Conclusion}

The conducted studies showed that exterior finishing insulation plywood-based systems with the operating life of at least 15 years are a good exterior based on CBPB, wood chipboard and fiberboard for exterior design of buildings. Reasons for failure are summarized in Table. 4.

Using the calculation of the additional stresses arising in the material in the absence of the possibility of free expansion when the temperature increases, it was proved that during installation of exterior finishing insulation plywood-based systems there is no need for the gap because the extra voltage does not exceed $1 \mathrm{MPa}$.

The strength margin of exterior insulation finishing systems with the size of plywood $60 \times 60 \mathrm{sm}$ is at least $95 \%$ for the Tambov region.

\section{References}

1. Erofeev A.V. (2013). Aktual'nye problemy stroitel'stva $i$ stroitel'noj industrii: Sbornik materialov XIV mezhdunarod. nauch.tehn. konf. [Proceedings of the XIV International scientific and technical conference]. Tula, pp. 33-34. (Rus)

2. Monastyrev P.V. (2000). Zhilishhnoe stroitel'stvo [Housing Construction], 5, pp. 14-15. (Rus)

3. Kulachkov V.N. (2000). Stroitel'nye materialy [Construction materials], 8, pp. 14-16. (Rus)

4. Prikshajtis M.P. (1995). Zhilishhnoe stroitel'stvo [Housing Construction], 9, pp. 21-23. (Rus)

5. Butovskij I.N. (1996). Zhilishhnoe stroitel'stvo, 9, pp. 7-10. (Rus)

6. Monastyrjov P.V. (2000). Tehnologija ustrojstva dopolnitel'noj teplozashhity sten zhilyh zdanij: ucheb. posobie [The technology of thermal protection of residential buildings: a tutorial], M.: Izd-vo ASV. (Rus)

7. Erofeev A.V. (2014). Dolgovechnye dekorativnozashhitnye plity na osnove drevesnyh kompozitov dlja fasadnoj otdelki zdanij: dis. ... kand. tehn. nauk: 05.23.05 [Durable insulation finishing systems based on wood composite technology for exterior design of buildings: $\mathrm{PhD}$ dissertation], Voronezh. (Rus)

8. Erofeev A.V., Yartsev V.P. (2011). Sovremennye tverdofaznye tehnologii: teorija, praktika i innovacionnyj menedzhment: Materialy III Mezhdunarod. nauch.innovacion. molodezh. konf. [Proceedings of the III International research and innovation youth conference]. Tambov, pp. 79-81. (Rus)

9. Erofeev A.V., Yartsev V.P. (2013). Internet-vestnik VolgGASU, 1 (25), pp. 1-4, Retrived from http://vestnik.vgasu.ru. (Rus)

10. Yartsev V.P., Erofeev A.V. (2012). Aktual'nye problemy stroitel'stva $i$ stroitel'noj industrii: Sbornik materialov XIII mezhdunarod. nauch.-tehn. Konf. [Proceedings of XIII International Scientific-Technical Conference], Tula, pp. 122-123. (Rus) 